\title{
Economic cost-benefit analysis for the agricultural use of sewage sludge treated with lime and fly ash
}

\author{
Efrat Hadas $^{1} \cdot$ Uri Mingelgrin ${ }^{2} \cdot$ Pinchas Fine $^{2}$
}

Received: 10 July 2020/Revised: 9 February 2021/Accepted: 29 April 2021/Published online: 31 May 2021

(C) The Author(s) 2021

\begin{abstract}
A tool for calculating the economic and environmental impacts of the use of byproducts of industrial processes that can substitute for perishable resources was presented. This was exemplified by fly ash (the fine fraction of ash originating from coal burned to generate electricity and collected by filtering exhaust gases leaving the furnace), added to soil as a component of sewage sludge stabilized with fly ash and lime (NVS). Application to soil of NVS has potential agricultural and environmental advantages and disadvantages. The costs and benefits of such application were calculated using both a database and expert opinions. The calculations assumed a representative assemblage of soils and crops, with weights assigned to each crop type and soil characteristic. The annual weighted benefits (additional income for the farmer) and costs per hectare reached 324 \$ha and 131 \$/ha respectively. Major potential benefits include: Chemical fertilizer replacement, 159 \$/ha; Improvement to the soil's physical properties, 75 \$/ha; Supply of vital trace elements, 33 \$/ha. Major potential costs were: Regulatory limitations on marketing of crops pending proof of absence of risk of heavy metals or radionuclides accumulation in these crops, (17 \$/ha and $36 \$$ ha respectively); Application and incorporation cost, 50 \$ ha. The presented estimates of the costs and benefits refer to the array of soils and conditions typical to Israel. It is possible to maximize potential benefits by applying fly ash only to the most suitable agricultural soils while improper use of fly ash will increase the costs incurred from its use.
\end{abstract}

Keywords Byproducts recycling $\cdot$ Cost-benefit analysis $\cdot$ Fly ash $\cdot$ Liming $\cdot$ Sewage sludge

\section{Introduction}

Fly ash is a byproduct of burning coal to generate electricity and it is used primarily as a component in building and infrastructure materials while a relatively small quantity is used in agriculture. In the present study we calcu-

Uri Mingelgrin

uriming@agri.gov.il

Efrat Hadas

efrath@moag.gov.il

Pinchas Fine

finep@volcani.agri.gov.il

1 Investment Financing Department, Ministry of Agriculture and Rural Development, 68 Hamakabim Road, P.O. Box 15159, 7505101 Rishon LeZion, Israel

2 Agricultural Research Organization, Volcani Center, Institute of Soils, Water and Environmental Sciences, 68 Hamakabim Road, P.O. Box 15159, 7505101 Rishon LeZion, Israel lated the costs and benefits of fly ash use in agriculture with the aim of demonstrating the considerable potential benefit of such use. Fly ash is primarily applied to soil admixed in sewage sludge pasteurized with lime and the ash. Upon the dissolution of the lime (about $10 \%$ of the sludge weight), the sludge heats up $\left(>70{ }^{\circ} \mathrm{C}\right)$, the $\mathrm{pH}$ rises $(>12)$ and the fly ash (sludge to ash ratio of 1:1) fluidizes the sludge, enabling close contact between the sludge and the lime.

Application of sludge stabilized with lime and fly ash (N-Viro Soil ${ }^{\circledR}$; NVS) to agricultural soils, substitutes for fertilizer inputs (Fine et al. 2014), improves the structure of 
problematic soils (Korcak 1995; Fine and Mingelgrin 2018) and reduces the infectiousness of plant pathogens in sandy soils (Gips 2008; Fine and Mingelgrin 2018). Pasteurization of sewage sludge using lime and fly ash is a simple process, which is also applicable to sludge of primary sewage treatment (Logan and Burnham 1994). In contrast, composting requires the early, expensive anaerobic digestion aimed at reducing volatile components. In practice, the agricultural value of NVS increases as the level of preliminary treatment of the sludge is reduced due to the higher availability of nutrients (Fine 2015). The main disadvantages in using NVS as compared to other soil additives rich in organic matter, are the fact that the sludge component in the NVS comprises only $50 \%$ of the final product (up to $15 \%$ of the dry matter) and the fact that the final product's volume is greater than that of the raw sewage as its density drops considerably. However, one outstanding advantage of NVS for the farmer is that its cost is borne by the urban sector (which on its part, benefits from a relatively low cost of sludge removal), and currently, the direct cost to the farmer in Israel is mainly the cost of NVS incorporation into the soil.

The use of fly ash offers considerable environmental benefits. As a constituent of the NVS, the contributions of fly ash to the environment include: Reduction in the release of ammonia and other greenhouse gases which occurs during sludge composting or the manufacture of chemical fertilizers; Replacement of non-renewable resources (including fossil fuels used to manufacture commercial fertilizers or mined phosphorous-containing minerals). Finally, fly ash application to soils can reduce the need for applying pest-controlling chemicals and its use conform to the recycling (or zero-waste) principle.

\section{Methodology: the economic calculations}

A number of investigations employed the LCA (life cycle analysis) methodology to reach a quantitative estimate of the effects of the use of fly ash (e.g., Epstein et al. 2011; Hong et al. 2013). These studies concentrated by and large on the benefits accruing from that use rather than on an overall economic balance which encompasses both costs and benefits, including the value of environmental effects. Likewise, the IPCC (Intergovernmental Panel on Climate Change) published a report estimating the damage due to greenhouse gasses for the years 2005-2006 (IPCC 2006), with the environmental costs (rather than the cost/benefit balance) evaluated by an LCA-type methodology. The methodology presented in this study for estimating the cost and benefit to farmers of the use of coal ash, is based on itemizing the benefits and costs and assigning a value to each item in nominal terms. Thus, it is possible to sum up the cost or the benefits and compare the total cost to the total benefit. Although the proposed methodology is applied in the present study to the estimation of the costs and benefits of the application of NVS to the array of agricultural soils and conditions prevalent in Israel, this methodology can be employed for calculating the economic and environmental impacts of the use of a byproduct of any industrial process that can substitute for non-renewable resources.

The price of fly ash is based on its value to the specific consumer (e.g., industry, construction, road infrastructures or agriculture) and that includes expenses such as transportation and application costs as well as its scarcity (shadow) price. Presently, demand for fly ash in Israel exceeds its supply, which is expected to drop further due to the planned reduction in the future use of coal for electricity generation. The possible environmental effects (benefits and damages) of using fly ash must also be given their appropriate weight in determining the true price of fly ash. Estimating the environmental costs and benefits is linked primarily to a market failure arising from the fact that environmental effects which are difficult to estimate, are not taken into account in determining the market price. Environmental costs and benefits when applying fly ash (as NVS) to agricultural fields are presented in this study in terms of quantified revenues and annual costs per hectare. It may be possible to improve the precision of the estimates by including additional advantages and disadvantages of NVS application (if such can be defined) and by refining the methodology needed to calculate the economic value of each.

The data used in the cost-benefit calculations, including the estimated effects of field application of fly ash embedded in NVS on the environment, were extracted from relevant research work performed in Israel (e.g., Fine and Mingelgrin 2018; Shargil et al. 2015; Teutsch 2018) and around the world (e.g., Logan and Burnham 1994; Korcak 1995; Veeresh et al. 2003; Manoharan et al. 2010) and from interviews with agronomists, both at the Israeli Ministry of Agriculture and in the private sector, whose assessments were translated into monetary terms. One primary, obvious benefit arising from the application of NVS is the increase in yield, but we have tried to break down and estimate the value of individual factors contributing to the higher yields (more efficient use of plant nutrients, improvement in soil structure, etc.) and therefore, the higher yield itself is not treated directly as a benefit.

In performing the calculations, the following assumptions were made:

(1) Fly ash is applied at the standard NVS application rate adopted in Israel $-50 \mathrm{~m}^{3}$ of NVS per hectare. 
(2) Application to any given area is limited to once every five years (even though it is permitted to apply NVS every year).

(3) Revenues and costs are calculated per hectare per year. When they are spread over a number of years, they are calculated using standard accounting principles, spreading the cost over five years and using $7 \%$ capitalization interest (in economic terms, this type of payment spread is defined as PMT). The rate of interest for capitalization was set at $7 \%$ as this is the accepted practice for investments in agriculture in Israel.

(4) Costs and revenues are converted into U.S. Dollar according to the average prices in 2019.

(5) An exposure coefficient was determined for every benefit, damage or risk-namely, the fraction of the relevant entity (e.g., total cultivated area or total yield) which it is reasonable to assume will generate a given benefit or will incur a given cost due to the application of the NVS. In the absence of any other information, it was assumed that the exposure level was equal to the ratio between the size of the area to which the benefit or the damage was applicable (for example only sandy soils) and the total area available for the application of NVS. Whenever information enabling a more accurate estimate was available (e.g., from the aforementioned recommendations and estimates made by experts), the exposure coefficient was determined accordingly.

As mentioned above, the reported estimates of the costs and benefits refer to the array of agricultural soils and conditions typical to Israel which is by and large a semiarid country. These costs and benefits may be rather different in other climatic zones and under different agricultural practices. Thus, in regions where acid soils are prevalent and liming is practiced, a rise in the $\mathrm{pH}$ of the soil is highly beneficial, (for example mitigating damage to crops due to $\mathrm{Al}$ or $\mathrm{Mn}$ toxicity). In such regions, as opposed to Israel, applying NVS as a liming agent may constitute a major benefit. Also, in considering the calculated costs and benefits it should be born in mind that it is possible to maximize potential benefits by applying fly ash only to the most suitable agricultural soils while improper use of fly ash will increase the costs incurred from its use. The elemental composition of the NVS used in Israel and of its source materials, coal combustion fly ash and untreated, secondary, aerated excess activated sewage sludge are presented in Table 1. The values are medians of 4-11 samples computed from data supplied by the NVS producer, DAN-VIRO, Israel.

In the following, a list of the benefits, the costs and examples of the equations used for their quantification is
Table 1 Elemental content and selected properties of NVS and its components coal combustion class F fly ash and untreated, secondary, aerated activated sewage sludge

\begin{tabular}{|c|c|c|c|}
\hline Parameter & Sludge & Fly ash & $\mathrm{N}$-viro soil \\
\hline Dry matter $(\mathrm{g} / 100 \mathrm{~g})$ & 18 & 100 & 60 \\
\hline Organic matter $(\mathrm{g} / 100 \mathrm{~g})$ & 15 & 1 & 8 \\
\hline Specific density (kg/L) & 1 & & 0.85 \\
\hline $\mathrm{pH}$ & 6.3 & 11.5 & 12.2 \\
\hline Total N (mg/kg dry) & 76,177 & 562 & 7601 \\
\hline $\mathrm{N}-\mathrm{NH}_{4}(\mathrm{mg} / \mathrm{kg}$ dry $)$ & 12,159 & 51 & 493 \\
\hline Total P (mg/kg dry) & 13,188 & 1827 & 3570 \\
\hline Total K (mg/kg dry) & 4297 & 1493 & 1395 \\
\hline $\mathrm{Ag}$ (mg/kg dry) & 5.3 & $<0.5$ & $<0.5$ \\
\hline $\mathrm{Al}$ (mg/kg dry) & 1,881 & 13,678 & 11,358 \\
\hline As (mg/kg dry) & $<0.5$ & 17.5 & 11.0 \\
\hline B (mg/kg dry) & 23 & 184 & 104 \\
\hline $\mathrm{Ba}(\mathrm{mg} / \mathrm{kg}$ dry) & 92 & 527 & 437 \\
\hline $\mathrm{Be}(\mathrm{mg} / \mathrm{kg}$ dry $)$ & 37 & 1 & 2 \\
\hline $\mathrm{Ca}(\mathrm{mg} / \mathrm{kg}$ dry) & 16,820 & 15,466 & 65,853 \\
\hline $\mathrm{Cd}$ (mg/kg dry) & $<2$ & $<2$ & $<2$ \\
\hline Co (mg/kg dry) & 1.8 & 7.9 & 7.9 \\
\hline $\mathrm{Cr}$ (mg/kg dry) & 30 & 14 & 30 \\
\hline $\mathrm{Cu}$ (mg/kg dry) & 130 & 17 & 41 \\
\hline $\mathrm{Fe}(\mathrm{mg} / \mathrm{kg}$ dry) & 2840 & 13,037 & 7312 \\
\hline $\mathrm{Hg}$ (mg/kg dry) & $<0.5$ & $<0.5$ & $<0.5$ \\
\hline Li (mg/kg dry) & 1.7 & 22.4 & 31.0 \\
\hline $\mathrm{Mg}$ (mg/kg dry) & 3497 & 3704 & 3349 \\
\hline Mn (mg/kg dry) & 53 & 174 & 137 \\
\hline Mo (mg/kg dry) & 3.0 & 6.2 & 5.7 \\
\hline $\mathrm{Na}$ (mg/kg dry) & 1135 & 1504 & 1378 \\
\hline Ni (mg/kg dry) & 19 & 17 & 17 \\
\hline $\mathrm{Pb}$ (mg/kg dry) & 17 & 5 & 9 \\
\hline S (mg/kg dry) & 5993 & 1762 & 2379 \\
\hline $\mathrm{Sb}$ (mg/kg dry) & 4.0 & $<3$ & $<3$ \\
\hline $\mathrm{Se}(\mathrm{mg} / \mathrm{kg}$ dry) & 4.4 & $<3$ & $<3$ \\
\hline $\mathrm{Si}(\mathrm{mg} / \mathrm{kg}$ dry) & 288 & 268 & 672 \\
\hline $\mathrm{Sn}(\mathrm{mg} / \mathrm{kg}$ dry) & 12 & $<3$ & 4 \\
\hline $\mathrm{Sr}$ (mg/kg dry) & 67 & 453 & 445 \\
\hline V (mg/kg dry) & 5.5 & 43.6 & 54.0 \\
\hline Zn (mg/kg dry) & 668 & 41 & 115 \\
\hline
\end{tabular}

presented. Also given are the references that served as sources for the quantitative information used in the calculations. These references can be accessed through the Israel National Coal Ash Administration's website at the address: http://www.coal-ash.co.il/tab_publish_plan.html. 


\section{Benefits from the application of fly ash as a constituent of NVS}

\subsection{Replacement of chemical fertilizers and soil fertility improvement}

NVS contains a higher fraction of organic matter than most mineral soils and its application increases organic matter content in the root zone, the magnitude of the increase being a function of the quantity applied per area and the amount of sludge in the additive. The application of $50 \mathrm{~m}^{3}$ of NVS per hectare adds $320 \mathrm{~kg}$ of nitrogen, $152 \mathrm{~kg}$ of phosphorus and $60 \mathrm{~kg}$ of potassium (Table 1). Based on the above total values, the available $\mathrm{N}$ and $\mathrm{P}$ in the first year after application are approximately 150 and $40 \mathrm{~kg} / \mathrm{ha}$. Fertilizer prices (per $\mathrm{kg}$ of pure element, nominal price) are: Nitrogen $1.95 \$ / \mathrm{kg}$; phosphorus $1.57 \$ / \mathrm{kg}$; and potassium $0.88 \$ / \mathrm{kg}$. Therefore, using a calculation based on the total value accumulated over five years (at $7 \%$ interest) and computing the average price per year, the annual savings in fertilizer application is 159 \$/ha. The exposure coefficient is 1 , because the contribution applies to all the areas treated with NVS.

\subsection{Higher soil water availability (WI)}

The pozzolanic properties of fly ash and hence of NVS as well, may improve the soils' physicochemical properties. This is especially significant in more sandy soils in which NVS addition improves the otherwise poor water holding capacity, thus generating higher water availability and soil stabilization against wind erosion. It is assumed that the increase in yield due to the improved water availability in the NVS-treated soil should be similar to the differences in yield between areas in which the rainfall differs in an amount that contributes to the soil's water content a quantity equivalent to the increase in water availability due to NVS application. The effect of NVS application to a sandy soil is to approximately double the water content at field capacity from about $2.5 \%$ to about $5 \%$ and hence an increase in available water content in the root zone contributed by $6 \mathrm{~mm}$ rain (Bar-Tal 2008). The contribution made by rainfall to grain yields in areas above the drought line (rainfall of $200 \mathrm{~mm} /$ year) per hectare is $10 \mathrm{~kg} / \mathrm{mm}$ under normal fertilizing conditions and therefore, the expected rise in grain yield will be $60 \mathrm{~kg} / \mathrm{ha}$, which produces a $3 \%$ change in net income. This can be expressed as:

$\mathrm{WI}=\mathrm{YR} \times \mathrm{RE} \times(0.2)$

where, YR is the rate of change (3\%) of the average annual profit margin per hectare (RE). The annual profit margin was determined according to the standard profit margin on wheat at $489 \$ / \mathrm{He} ; 3 \%$ of which is $14 \$ /$ ha. Given that sandy soils constitutes roughly $20 \%$ of the area available for application of NVS, the exposure coefficient was taken as 0.2 and the weighted benefit was therefore $4 \$ / \mathrm{ha}$.

\subsection{Improvements to the soil's physical properties} (TL)

As stated above, fly ash addition can improve marginal soils by raising water retention capacity in sandy soils; by stabilizing dune sands against wind erosion (for example by encouraging the formation of biological crusts); by reducing runoff from crust-forming soils such as loess; and by reducing plasticity and cracking in high-sodium, clayey soils.

The calculation of the associated benefits was performed on a potato crop. Potatoes are an important crop in the light soils of the northwestern Negev, a law-rainfall region in the south of Israel. It was assumed that loss of yield due to wind erosion occurs at a frequency of once every 15 years (F). The average net income (RE) is 1367 \$/ha (Gal and Medlag 2012) and the interest rate used was again taken as $7 \%$. The estimated benefit (TL) arising from soil improvements achieved by the application of fly ash or NVS is:

$\mathrm{TL}=\operatorname{PMT}($ Rate $, F, \mathrm{RE})=150 \$ /$ ha

Prevention of runoff and erosion (caused by either wind or water) is relevant to a wide range of soils, but given that most of the benefit can be expected to accrue in sandy and loessial soils, we shall only consider those soil types and hence the exposure coefficient was taken to be 0.5 and the weighted benefit was estimated at $75 \$ /$ ha.

\subsection{Reduced demand for irrigation water $(Q)$}

Higher water retention capacity in the soil achieved by the addition of fly ash enables saving of irrigation water. This refers mainly to pre-sowing irrigation, meant to ensure germination and crop establishment. It was assumed that the volume of pre-sowing supplementary irrigation is around $500 \mathrm{~m}^{3} /$ ha and that in sandy soils it was possible to save $100 \mathrm{~m}^{3} / \mathrm{ha}(S)$ by adding fly ash or NVS. Given that the cost of irrigation water $(P)$ is $0.41 \$$ per $^{3}$, the value of the reduction in irrigation water volume is:

$Q=S \times P$

or total savings of $41 \$ / \mathrm{ha}$. About one third of the total area available for the application of NVS is irrigated and therefore, the exposure coefficient is 0.3 and the weighted benefit is $12 \$ / h$. 


\subsection{Reduction in loss of nutrients by leaching}

It is assumed that most of the loss by leaching involves mineral nitrogen and that under Israeli conditions (semiarid), the leaching of other nutrients is negligible. As compared with chemical fertilizers, the release of nitrogen from manure is relatively slow, slowing down its leaching. Nitrogen use efficiency under cereals is assumed to be $\sim$ $50 \%$ of the applied N fertilizer (Raun and Johnson 1999) and it is reasonable to assume that only about $25 \%$ of the mineral nitrogen formed by mineralization of the organic nitrogen present in the manure component of the NVS will be leached due to its slow release character. This is about half the leaching rate of the mineral nitrogen applied as a commercial fertilizer which is exposed to leaching from the moment it is applied to the soil. Accordingly, measurements taken in a sandy, commercial field have shown that the efficiency of use of nitrogen applied as NVS was much higher than the efficiency of nitrogen added as a commercial fertilizer, much of which was leached away (Fine and Mingelgrin 2018). Based on the conservative assumptions detailed above, the decrease in loss of nitrogen by leaching in rain-fed fields was $50 \mathrm{~kg} / \mathrm{ha}$, valued at $100 \$ /$ ha. In irrigated areas, fertilization is better regulated (e.g., by fertigation) and the leaching potential is hence lower. Accordingly, the exposure coefficient was taken as 0.8 and when spread out over five years, the benefit from applying NVS was calculated to be $18 \$ /$ ha. It should be noted that preventing nitrogen leaching has environmental benefits the value of which was not quantified.

\subsection{Reducing of plant pathogens and weeds in soils}

The biocidal effect of NVS results from the formation of gaseous ammonia. The high $\mathrm{pH}$ of NVS causes the release of ammonia gas into the soil (e.g., Gips 2008), the ammonia either originating from nitrogenous species in the applied NVS or being supplemented as fertilizer (anhydrous ammonia or ammonium sulfate salt). This biocidal activity can be utilized to save some of the cost of soil disinfection often practiced for field crops. We assumed conservatively that the saving would be 136 \$ha, effective only in the year of NVS application. When spread out over five years, the saving will be $33 \$ /$ ha per year. Adopting an exposure coefficient is 0.3 , (only irrigated areas, because gaseous ammonia release from the NVS or from added ammonium salt requires the presence of an aqueous phase), the weighted benefit is $10 \$ /$ ha .

\subsection{Contribution of essential micronutrients}

Application of fly ash or NVS contributes vital trace elements as was demonstrated for a range of crops and soils (e.g., Ukwattage et al. 2013 and Table 1). Although the benefits accruing from the addition of trace elements is calculated in the present study on the basis of its value to the farmer, some elements such as selenium and molybdenum which originate in the fly ash are beneficial to human health and in the future it may be possible to charge the customer for their presence in the product. Thus, on packages of potato chips produced in Italy under the tradename Selenella appears the statement that it is rich in selenium as a sales promoting slogan. The cost of a single application of trace elements is estimated at 54 \$/ha and three applications are normal practice for vegetable crops per growing season. Addition of trace elements is not a standard practice for field crops, but higher micronutrients uptake and yield were observed (e.g., in forage legumes) even five years after NVS application. For the sake of conservative calculations it was assumed that the micronutrients will be available to vegetables only during the year of NVS application. Assuming a total value of 163 $\$ /$ ha for the vegetable crops, 38 \$/ha per year over five years was the value assigned to the added microutrients. For field crops, the total savings was estimated to be $54 \$$ / ha during the first year and the availability goes down gradually over the next four years to yield an average of 30 $\$ /$ ha per year. Assuming that this applies to all the areas treated with NVS and that the area of intensive (e.g., vegetable) cropping is one quarter of the total cultivated area, the weighted advantage for the total area is $33 \$ /$ ha (according to $38 \times 0.25+30 \times 0.75$ ) .

\subsection{Higher soil temperatures}

Application of fly ash or NVS darkens the surface of light colored soils (e.g., sand or loess), thus decreasing their albedo and causing their surface to heat up. That could be advantageous for winter vegetables such as potatoes (for which the profit margin is $1358 \$ / \mathrm{ha}$ ). Potatoes are mostly grown in Israel in the light soils of the northwestern Negev which is exposed to frost events at an average frequency of once every 5 years. Given that the effects of NVS on soil temperature are not known, a minimum value was taken of a $10 \%$ reduction in loss of yield due to a frost event. This provides a benefit of $33 \$ / \mathrm{ha}$ per year. The exposure coefficient used was 0.4 (sand and loess areas) and the weighted benefit was thus estimated at $13 \$ /$ ha. In contrast, excessive heating of the soil in the summer will have a negative effect and if it becomes necessary to cool potatoes before harvesting in the summer, irrigation will be applied. Such an event will, of course, decrease the value of the elevation in soil temperature. 


\subsection{Summary of the benefits}

The principal advantages arising from the application of NVS to agricultural soils are the addition of the major plant nutrients (nitrogen, phosphorus and potassium); Reduction in nitrogen loss (dry land cropping); Addition of essential trace elements; Rise in the organic matter content in the soil (resulting in better soil structure); Reduction in soil borne diseases; And better water retention.

\section{The costs of agricultural application of fly ash or NVS}

\subsection{Higher soil salinity}

Application of the recommended quantities of NVS using the appropriate application regime, should not increase salinity. Yet, the application of large quantities (such as those required at times to control soil borne diseases), might cause salinity damage, mostly due to addition of the soluble nitrate. The calculation of the cost of salinization damage was performed based on an estimate of the quantity of soluble salts added with the NVS application (about $154 \mathrm{~kg} / \mathrm{ha}$ ) and the cost of flushing out the salt (assumed to be equivalent to the cost of removing by desalination the above quantity of salt at $0.33 \$ / \mathrm{kg}$ salt). The calculated cost of the salt added to the soil once every five years is accordingly $52 \$ /$ ha and in annual terms at market interest rates, that means $13 \$ /$ ha per year. Assuming that the aforementioned cost refers only to dry land cropping, the exposure coefficient is 0.5 and the weighted annual cost is 6 \$/ha. That is a stringent assessment because, as state above, under a proper application regime there will not be any salinization damage since most of the salinity is due to addition of nitrogen (an essential nutrient) as nitrate and during the years following application the nitrate will disappear by plant and microbial uptake, chemical transformations and leaching.

\subsection{Contamination by heavy metals and other toxic elements}

Field trials using fly ash and NVS demonstrated that the concentration of toxic elements (e.g., cadmium, lead and arsenic) in test plants grown in fields to which NVS or fly ash were applied, were usually very low and similar to the concentrations in the commercial control. Yet, regulatory agencies expressed fear that the application of fly ash to agricultural land may result in the accumulation of toxic metals in the environment and in the crops. Accordingly, it was required by the Israeli Ministry of health that edible crops grown on a NVS-loaded soil must be monitored for a number of years before approval is granted for their marketing. Since such crops cannot be marketed during the monitoring period, the farmer incurs a significant, albeit temporary, loss caused by the reduced availability of cropping alternatives. Prohibition of marketing leafy vegetables for three years was chosen as a representative scenario. In that case a loss of income estimated at $543 \$ /$ ha per year (Gal and Medlag 2012; the difference between the average value of leafy vegetables and of root vegetables) is incurred. With an exposure coefficient of $5 \%$ out of the entire area treated with NVS and spread over five years at $7 \%$ interest, the damage is estimated at 17 \$/ha per year.

\subsection{Contamination by radionuclides}

Although it is clear beyond any doubt that there is no danger of a buildup of radio-nuclides in the soil or in crops harvested from soils treated with fly ash or NVS (e.g., Koch 2002, 2010; Chakin 2013; Katz and Shwartz 2013 and laboratory results from testing various crops), monitoring for the presence of radionuclides continues in crops for years while these crops are not authorized for marketing. Not growing a vegetable crop was estimated to result in a loss of earnings totaling $543 \$ /$ ha per year (see Sect. 4.2 above). Assuming a 7 year prohibition period and an exposure coefficient of $5 \%$ of the total area available to NVS application and after spreading the loss over 5 years at $7 \%$ interest rate, the cost is estimated to be $36 \$ / \mathrm{ha}$ annually.

\subsection{Contamination by boron $(B)$}

Boron concentrations in fly ash and in NVS are higher than in most sludges and manures (e.g., Table 1) and therefore, application of NVS could lead to boron toxicity in sensitive crops. Yet, even if boron surplus accumulates in the soil, it is likely to disappear after a short time because boron is leached away easily by rain or irrigation water. In Israel, no damage caused by the presence of boron was observed even after the application of exceptionally large quantities of NVS in any crop, (e.g., Fine and Mingelgrin. 2018). Nevertheless, the potential risk to sensitive crops reduces in certain areas the choice of crops suitable for application of NVS. It was estimated, based on the rationale defined in Sect. 4.2 above, that the potential damage from excess boron would reach 543 \$/ha per year, but in view of boron's leachability, this damage would last for 2 years only. With a $5 \%$ level of exposure to particularly sensitive crops and at the aforementioned rate of interest for 5 years, the estimated cost would be 11 \$/ha per year.

$$
\begin{aligned}
B & =\operatorname{PMT}(7 \%, 5 \text { year, } \mathrm{PV}(7 \%, 2 \text { year, } 543) \times 0.05) \\
& =11 \$ / \text { ha }
\end{aligned}
$$


where, PV is the present value.

\subsection{Lower availability of phosphorus and trace elements native to the soil}

There is hardly any evidence of reduced availability of any essential elements due to NVS or fly ash application (including in four experiments involving ground nuts, which are especially sensitive to iron deficiency, Fine et al. 2014; Fine 2015). Nevertheless, it was decided to take this possibility into account because of the potential rise in $\mathrm{pH}$ and soluble calcium content in soils amended with NVS (but see Sect. 4.6 below). Given that the content of trace elements in the soil rises following the application of NVS, it should suffice to add a chelate such as EDTA $(10 \mathrm{mg} / \mathrm{l}$ in $1500 \mathrm{~m}^{3}$ of irrigation water) to ensure their availability. The quantity of EDTA required would be $15 \mathrm{~kg}$ per hectare per season at a cost of 122 \$. Taking a conservative approach, the chances of any shortage of trace elements or $\mathrm{P}$ were assessed at $10 \%$ of the area grown to vegetables (about a third of the area available to NVS application and thus exposure coefficient of 3\%) for 5 years after application. Therefore, and the damage was estimated at 6 $\$ /$ ha per year.

\subsection{Rise in $\mathrm{pH}$ and the concentration of carbonate and calcium in the soil}

A rise in $\mathrm{pH}$ may occur upon NVS addition (Sect. 4.5 above), primarily in soils of low calcium carbonate content. A rise in $\mathrm{pH}$ and calcium concentration can reduce phosphorus and trace element availability to the plant, yet, no such damage was observed upon NVS or fly ah addition. The rise in $\mathrm{pH}$ that accompanies NVS application lasts only for a few hours or, at most, a few days after application and it soon disappears due to the carbonization process occurring in the soil following wetting of the soil and breakdown of the added organic matter found in the sludge component of NVS, a process accompanied by neutralization of available hydroxyls. Damage can, however, be caused by a lasting rise in $\mathrm{pH}$ if the application regime and post application management are not suitable. A reasonable estimate is that this will occur on about $10 \%$ of the dryland farming area (i.e., exposure coefficient of 0.1) and that the damage will reach $20 \%$ of the potential standard profit margin. The standard profit margin for dryland forage crops is 1087 \$/ha (Gal and Solomon 2014). The calculation for a five year period with the interest rate and other conditions as defined above, yields a cost of $5 \$ / \mathrm{ha}$ per year. Although the main potential damage is a reduction in the availability of phosphorus and trace elements in the soil (Sect. 4.5 above), in the interest of caution, we have treated this phenomenon separately so as to cover other, unexpected potential forms of damage which may be caused by a rise in $\mathrm{pH}$ and carbonate content in the soil.

It is important to note that a rise in the $\mathrm{pH}$ of the soil is highly beneficial in those climatic zones where liming is practiced to avoid damage to crops due to soil acidity (e.g., $\mathrm{Al}$ or $\mathrm{Mn}$ toxicity). In such areas, the rise in $\mathrm{pH}$ due to NVS application may constitute a significant benefit. However, since we chose as a sample calculation the estimated costs and benefits of NVS application to the array of soils existing in Israel under the conditions prevalent there (and thus applicable to semi-arid regions where soil $\mathrm{pH}$ is typically neutral and above), the considerable benefit of NVS as a liming agent was not taken into account.

\subsection{Application and incorporation}

NVS application costs around $2 \$$ per $\mathrm{m}^{3}$ and incorporation cost is again $2 \$$ per $\mathrm{m}^{3}$. Thus, application of $50 \mathrm{~m}^{3} / \mathrm{ha}$, assuming an exposure coefficient of 1 and NVS application once every five years, will involve an annual cost of $50 \$ /$ ha.

$\operatorname{PMT}(0.07,5,200) \times 1=50 \$ /$ ha

Table 2 Weighted benefits and costs of the application of fly ash or NVS to agricultural soils (in \$/ha; 2019 prices and under the assumptions stipulated in the text)

\begin{tabular}{|c|c|c|c|}
\hline Item & Benefit & Item & Cost \\
\hline $\begin{array}{l}\text { Replacement of } \\
\text { synthetic } \\
\text { fertilizers }\end{array}$ & 159 & Higher soil salinity & 6 \\
\hline $\begin{array}{l}\text { Higher soil water } \\
\text { availability }\end{array}$ & 4 & $\begin{array}{l}\text { Introduction to the soil of } \\
\text { heavy metals and other } \\
\text { toxic elements }\end{array}$ & 17 \\
\hline $\begin{array}{l}\text { Improvements to the } \\
\text { soil's physical } \\
\text { properties }\end{array}$ & 75 & $\begin{array}{l}\text { Introduction to the soil of } \\
\text { radionuclides }\end{array}$ & 36 \\
\hline $\begin{array}{l}\text { Savings in irrigation } \\
\text { water }\end{array}$ & 12 & Addition of boron to the soil & 11 \\
\hline $\begin{array}{l}\text { Reduced leaching of } \\
\text { nutrients }\end{array}$ & 18 & $\begin{array}{l}\text { Decreasing availability of } \\
\text { phosphorus and essential } \\
\text { trace elements in the soil }\end{array}$ & 6 \\
\hline $\begin{array}{l}\text { Reduction of plant } \\
\text { pathogens and } \\
\text { weeds in soils }\end{array}$ & 10 & $\begin{array}{l}\text { Elevation of } \mathrm{pH} \text { and } \\
\text { concentration of } \\
\text { carbonates and calcium in } \\
\text { the soil }\end{array}$ & 5 \\
\hline $\begin{array}{l}\text { Addition of essential } \\
\text { micronutrients }\end{array}$ & 33 & $\begin{array}{l}\text { Application and } \\
\text { Incorporation }\end{array}$ & 50 \\
\hline $\begin{array}{l}\text { Higher soil } \\
\text { temperature }\end{array}$ & 13 & & \\
\hline $\begin{array}{l}\text { Total weighted } \\
\text { benefit }\end{array}$ & 324 & Total weighted cost & 131 \\
\hline
\end{tabular}




\section{Summary and conclusions}

Table 2 summarizes the results of the cost-benefit analysis of long term use of fly ash and NVS in agriculture in terms of the potential annual damage and benefit per hectare. Short and long term effects of the application of fly ash and NVS on crops, the soil and the environment determine the economic viability of the application for the farmer. NVS can replace chemical fertilizers while offering an added benefit of slow release, improve the soil's physical and chemical properties and help control weeds and soil borne pathogens. Most studies, both in Israel and around the world show that the proper application of fly ash as a component of NVS can improve the fertility of soils and that under all reasonable circumstances such applications do not adversely affect the quality of the soil as a substrate for growing plants. The agricultural use of NVS contributes not only to the profitability and the sustainability of the agricultural enterprise, but it also contributes to the quality of the rural and urban environments. The contribution to the environment arises, for example, from eliminating ammonia and greenhouse gases emission which occurs during sludge composting or the manufacture of chemical fertilizers. NVS amendment results in a reduction in the use of non-renewable resources (e.g., fossil fuel used for the manufacture of commercial fertilizers or minerals containing phosphorus, potassium or trace elements quarried for the production of such fertilizers.). Finally, NVS can be used as a partial substitute for pest-control chemical agents and, since it contains sludge and coal ash, its use conforms to the maximum-recycling principle. The redirection of NVS to agriculture after a very cost-efficient process of sludge-pasteurization, contributes to the urban sector by reducing the cost of both sludge treatment and removal.

The assessment of costs and benefits conducted in this study is based on conservative and stringent assumptions such as the inclusion of the costs of potential damages even if the likelihood of their occurrence is extremely low. Cost calculations took into account the concern for long term damage to the soil caused by unforeseen factors associated with the application of fly ash, notwithstanding the fact that the information and experience accumulated over the years on all matters pertaining to the application of NVS to agricultural soils indicate that the likelihood of such damage to occur is slight. Field trials conducted in Israel and elsewhere, as well as the many years in which NVS has been used in commercial fields, prove that the risk of long term damage due to its application to the soil is very low. Nevertheless, monitoring continues in those areas where NVS was applied, in the manner in which any new additive is monitored, so as to remove all doubts about possible damages as unlikely as they may be.

Acknowledgements This work was funded by the Israel National Coal Ash Board (INCAB) Grant \#39477. The authors wish to express their deep gratitude to the late Mr. Omri Lulav, Head of the INCAB.

Open Access This article is licensed under a Creative Commons Attribution 4.0 International License, which permits use, sharing, adaptation, distribution and reproduction in any medium or format, as long as you give appropriate credit to the original author(s) and the source, provide a link to the Creative Commons licence, and indicate if changes were made. The images or other third party material in this article are included in the article's Creative Commons licence, unless indicated otherwise in a credit line to the material. If material is not included in the article's Creative Commons licence and your intended use is not permitted by statutory regulation or exceeds the permitted use, you will need to obtain permission directly from the copyright holder. To view a copy of this licence, visit http://creativecommons. org/licenses/by/4.0/.

\section{References}

Bar-Tal S (2008) The use of fly ash to improve marginal soils in applicl. MSc thesis, the Hebrew University of Jerusalem, $68 \mathrm{p}$ (in Hebrew with English abstract)

Chakin G (2013) Absorption of radionuclides by agricultural produce-position paper. Submitted to the Israel National Coal Ash Board (INCAB) (in Hebrew)

Epstein PR, Buonocore JJ, Eckerle K, Hendryx M, Stout BM III, Heinberg R, Clapp RW, May B, Reinhart NL, Ahern MM, Doshi SK, Glustrom L (2011) Full cost accounting for the life cycle of coal. Ann NY Acad Sci 1219:73-98. https://doi.org/10.1111/j. 1749-6632.2010.05890

Fine P (2015) Assessment of advisability of applying manures as an alternative fertilizer for field crops. Nir VeTelem 59:21-26 (in Hebrew)

Fine P, Mingelgrin U (2018) The effect of land application of sludge stabilized with coal fly ash and lime on soil and crop quality. In: Adams T (ed) Ash at work, applications, science, and sustainability of coal ash. Issue 1 2018. American Coal Ash Association, MI, USA, pp 10-13. https://www.acaa-usa.org/Portals/9/ Files/PDFs/ASH01-2018.pdf

Fine P, Bosak A, Berezkin A, Levkowitz I, Suryano S, Elya M, Eizencot A, Ostrovsky G, Kilman Y (2014) Assessment of sludges and urban wastes as replacements for chemical fertilizers in field crops. Nir VaTelem 56:27-35 (in Hebrew)

Gal B, Medlag J (2012) Vegetable crop calculations. Ministry of Agriculture and Rural Development (in Hebrew)

Gal B, Solomon A (2014) Field crop calculations. Ministry of Agriculture and Rural Development (in Hebrew)

Gips A (2008) Control of soil-inhabiting pathogens using ammonia. $\mathrm{PhD}$ Thesis, Hebrew University (Hebrew with English abstract). http://shemer.mslib.huji.ac.il/dissertations/W/AGR/ 001494915.pdf

Hong J, Xu C, Hong J, Tan X, Chen W (2013) Life Cycle Assessment of sewage sludge co-incineration in a coal-based power station. Waste Manag 33:1843-1852

IPCC (2006) 2006 IPCC guidelines for national greenhouse gas inventories. In: Eggleston HS, Buendia L, Miwa K, Ngara T, Tanabe K (eds) Prepared by the national greenhouse gas inventories programme. IGES, Japan. http://www.ipcc-nggip. iges.or.jp. Last visited Jan 2020 
Katz G, Shwartz A (2013) Survey of Metals and Radionuclides in crops treated with DAN-VIRO fertilizers: report on analytical findings-expert opinion. Submitted to the Israeli National Coal Ash Administration and the Ministry of Health. 21 pages (in Hebrew)

Koch J (2002) Assessment of exposure to ionizing radiation when using coal ash in agriculture. Radiation Safety Unit, the Nuclear Research Center, Nahal Sorek, 2002. Position paper submitted to the Israel National Coal Ash Board (INCAB)

Koch J (2010) Exposure to radiation from stabilized sewage sludge. Radiation Safety Unit, the Nuclear Research Center, Nahal Sorek, 2002. Position paper submitted to the Israel National Coal Ash Board (INCAB)

Korcak RF (1995) Utilization of coal combustion by-products in agriculture and horticulture. In: Karlen DL, Wright RJ, Kemper WO (eds) Agriculture utilization of urban and industrial byproducts, ASA Special Publication No 58. ASA, CSSA, NVSA, Madison, Wisconsin, pp 107-130

Logan TJ, Burnham JC (1994) The alkaline stabilization with accelerated drying process (N-Viro): an advanced technology to convert sewage sludge into a soil product. In: Karlen DL, Wright RJ, Kemper WO (eds) Agriculture utilization of urban and industrial by-products, ASA Special Publication No 58. ASA, CSSA, NVSA, Madison, Wisconsin, pp 209-223

Manoharan V, Yunusa IAM, Loganathan P, Lawrie R, Murray BR, Skilbeck CG, Eamus D (2010) Boron contents and solubility in
Australian fly ashes and its uptake by canola (Brassica napus L.) from the ash-amended soils. Aust J Soil Res 48:480-487. https:// doi.org/10.1071/SR10073

Raun WR, Johnson GV (1999) Improving nitrogen use efficiency for cereal production. Agron J 91:357-363. https://doi.org/10.2134/ agronj1999.00021962009100030001x

Shargil SD, Gerstl Z, Fine P, Nitsan I, Kurtzman D (2015) Impact of biosolids and wastewater effluent application to agricultural land on steroidal hormone content in lettuce plants. Sci Total Environ 505:357-366

Teutsch N (2018) Environmental assessment of coal fly ash usage in agriculture and infrastructure projects in Israel. In Adams T (ed) Ash at work, applications, science, and sustainability of coal ash. Issue 1 2018. American Coal Ash Association, MI, USA, pp 28-31. https://www.acaa-usa.org/Portals/9/Files/PDFs/ ASH01-2018.pdf

Ukwattage NL, Ranjith PG, Bouazza M (2013) The use of coal combustion fly ash as a soil amendment in agricultural lands (with comments on its potential to improve food security and sequester carbon). Fuel 109:400-408

Veeresh H, Tripathy S, Chaudhuri D, Ghosh B, Hart B, Powell M (2003) Changes in physical and chemical properties of three soil types in India as a result of amendment with fly ash and sewage sludge. Environ Geol 43:513-520 